\title{
Yayalaştırılmış Bir Bölge: Antalya-Cumhuriyet Caddesi
}

\author{
*H. Sanem ÇINAR ALTINÇEKİÇ', Buket DOKTUR ${ }^{2}$ \\ ${ }^{1}$ İstanbul Üniversitesi Orman Fakültesi Peyzaj Planlama ve Tasarımı Anabilim Dalı \\ 34473 Bahçeköy/İstanbul / Türkiye \\ ${ }^{2}$ Peyzaj Mimar1, Türkiye \\ *Sorumlu yazar: saneme@istanbul.edu.tr
}

\begin{abstract}
Özet: Toplum etkileşimi için güvenli- konforlu- erişilebilir alanlar, sürdürülebilir ve yaşanabilir kentlerin en temel bileşenidir. $\mathrm{Bu}$ nedenle kentsel alanda, cazibe merkezi niteliği taşıyacak, araç trafiğinden arındırılmış yaya öncelikli alanlar sunmak, sosyal, estetik ve ekonomik açıdan gereklidir. Kentsel alanlarda var olan ya da yeniden yapılandırılması düşünülen yaya bölgelerinin sürdürülebilirliği için, planlama ve tasarım sürecine kentlinin katılımının sağlanması, ihtiyaç ve önerilerinin belirlenmesi açısından akılcı bir yöntem olacaktır. Bu bağlamda, Antalya kent merkezinde yer alan Cumhuriyet Caddesinde gerçekleştirilen gözlem ve etütler, fotoğraf çekimleri ve yapılan anket çalışması ile farklı yaş, cinsiyet ve meslekten 100 kişiye, bu çalışma için hazırlanmış sorular (alanın kullanım amacı, sıklığı, alana ulaşım şekli, alanın üzerlerinde bıraktığı etki, eksik donatı ve etkinlikler gibi) yöneltilmiştir. Cumhuriyet Caddesi örneğinde fiziksel ve sosyal çevre verileri ile kullanıcıların görüşleri ve istekleri saptanarak, kullanıcı memnuniyeti analiz edilmiş, kullanıcı görüşleri doğrultusunda değerlendirilerek Antalya kent merkezinin en önemli yaya bölgelerinden olan araştırma alanı için öneriler getirilmiştir.
\end{abstract}

Anahtar kelime: Yaya, Yaya bölgesi, Kentsel alan, Antalya, Cumhuriyet caddesi

\section{A Region that Pedestrianized: Antalya Cumhuriyet Avenue}

\begin{abstract}
Safe, comfortable and accesible areas for the society interaction are the most important components for sustainable and inhabitable cities. Therefore its necessary in economic, aestethic and social way to provide areas that are free from vehicular traffic, act like an attraction point and give priority to pedestrians in urban areas. For the sustainability of the pedestrian zone that exists or thought to be restructured, citizen participation to the planning and designing process is a rational method to determine the needs and suggestions. In this context, the questions (the utilization purpose and frequency of this avenue, the transportation type, the impact of the area, missing pieces and events, etc.) that prepared from the observations, studies, photo shoots and surveys are directed to 100 people from different gender, age and proffesions about Cumhuriyet Avenue that takes places in the city center of Antalya. In the example of Cumhuriyet Avenue with determining the physical and social environmental datas and the comments and requests of users, user satisfaction analized and avaluated through the user opinions, suggestions are made for the research zone, which is one of the most important pedestrian zones of Antalya city center.
\end{abstract}

Keywords: Pedestrian, Pedestrian zone, Urban area, Antalya, Cumhuriyet avenue

\section{Giriş}

Yaya Bölgesi, taşıt veya yaya trafiğinin yoğun olduğu kent merkezlerinde yayalara daha güvenli ve rahat hareket imkânı sağlayan, kentin mimari yapısını bozmadan yaya trafiğine açılan çok yönlü işlevlerle donatılmış kentsel açık mekânlardır (Bayraktar ve ark, 1987).

Yaya bölgeleri planlanırken, yaya bölgelerinin gelişimini etkileyen bütün faktörler (fiziksel, işlevsel, sosyal, ekonomik faktörler gibi) ile ilgili bilgi toplanmalı ve bu bilgiler analiz edilmelidir. Yayalaştırma çalışmalarının sağlıklı, sürdürülebilir ve görsel kalitesi yüksek yaşam mekânları yaratmayı amaçlayan yapısal ve bitkisel peyzaj tasarımı çalışmalarıyla desteklenmesi gerekmektedir. Aksi takdirde, yayaların olduğundan daha hızlı hareket etmek zorunda oluşları, taşıtların ise yayalarla aynı ortamı paylaşmaları nedeniyle hız kesmek zorunda oluşları, her iki taraf için problem yaratacaktır (Kuntay 1994). Aynı zamanda yaya bölgeleri belirgin sınırlara, kimliğe, toplu taşım olanaklarına, kolay ulaşılabilirliğe ve otopark olanaklarına da sahip olmalıdır (Birişçi vd. 2002).

Yaya ulaşımında amaç; öncelikle yaya yolculuklarına mekân açmak ve aynı zamanda trafik karmaşasından arındırılmış, toplumsal 
ve kültürel yaşamı zenginleștiren mekânlar oluşturmak olmalıdır (Cebeci ve Çakılcıoğlu, 2001).

\section{Tarihte yaya bölgeleri}

Medeniyetlerin tarihi gelişimi incelenirken, hayatın başlica sahnesinin sokaklar olduğu görülür (Aru, 1965). Sokakta, yayalar ile arabalar arasındaki ilk çatışma, Roma'da yaşanmıştır. Sezar, Roma'da sabah güneş doğuşundan batışına kadarki sürede yayaların şehir içinde rahat hareket etmesini sağlamak için araba geçişini yasaklamıştır (Çınar, 2007).

Yaya ile araç yollarını kesin olarak birbirinden ayırma fikri ise, ilk olarak XV. yüzyılda Leonardo Da Vinci tarafindan ortaya konulmuş ve yayalar için farklı yükseltilerde yollar tasarlanarak yaya mekânları düzenlenmiş̦tir (Kuntay, 2008) ve tarihte bu durum kaldırıma ilk örnek olmuştur XVIII yüzyıl başlarında geometrik planlar içinde yine yaya trafiği ön plandadır (Renda, 1996). XIX. yüzyılda araçların artması ile kentler, sokaklar yayalar için daha tehlikeli alanlar olmaya başlamış ve bu nedenle yayalarla motorlu araçların birbirinden ayrılması gündeme gelmiştir. Bu amaçla XIX. yüzyıl ortalarında halk için parklar ve yürüme yolları tasarlanmıştır. Bunun ilk örneklerine İngiltere'de rastlanmıştır (Renda, 1996). XIX. yüzyılın sonlarına doğru şehirlerarası yolların mevcut kentlerin içinden geçirilmesiyle, kent örgüsü ve yaya mekânları bozulmaya başlamıştır (Özkal 1990). XX. yüzyılın başlarında yeni ulaşım sistemlerinin artmasıly kentler daha geniş alanlara yayılmaya başlamıştır. Raylı sistemler, istasyon çevresinde yeni dolaşım sisteminin oluşmasını sağlamıș, metrolar ise yaya dolaşımında farklı bir özellik ortaya koymuşlardır (Kavi, 2003). XX. yüzyılın ikinci yarısından itibaren ise yayalar, hızla artan motorlaşma endeksiyle kentlerde kendilerine yer bulamamaya başlamışlardır. Sayıları giderek artan motorlu taşıtlar, yaya yollarını, kaldırımları, meydanları, taşıt ulaşımı ve otopark gereksinimini karşılamak için kullanmaya başlamışlardır (Özkal, 1990). Günümüzde var olan trafik sorunu, yayaların şehirlerde can güvenliğinin kalmaması, gürültü ve hava kirliliği gibi taşıtların kentlerde yarattı̆ğ sorunları engellemek için ise, kent merkezlerinin taşıt trafiğine tamamen yada kısmen kapatılması ve yayalaştırılması gibi çözümler geliştirilmeye çalışılmıştır (Demir, 1999). Yaygınlaşan bu durum önemli bir kentsel planlama olgusudur.

\section{Yaya bölgesi düzenleme kriterleri}

Yaya bölgesi olarak planlanmak istenen alanın, toplu taşıma istasyonları ve otopark alan yeterlilikleri, mevcut yapiların mimari nitelikleri gibi kültürel özelliklerinin; topografya, iklim, bitki durumu gibi doğal özelliklerinin; nüfus, güvenlik, alandaki yapıların mülkiyet durumu gibi sosyoekonomik özelliklerinin ve alanın siyasi ve sermaye özelliklerinin belirlenmesi gereklidir (Demir, 1999). Bu alanlarda, sınırın net olarak tanımlanması planlamayı kolaylaştırmaktadır (Ökten ve Sancar, 2004). Alanın büyüklügüu, kullanic1 sayisina uygun olmalıdır (Untermann, 1991). Yaya bölgelerinin, kolay erişilebilir ve görülebilir, estetik çekiciliğe sahip, bakımının kolay, ekonomik ve güvenli olmas1 önemlidir (Francis,1991). Alan; konforlu ve kullanışlı olmalı, sosyal, çekici ve davet edici özellikler taşımalı, iștirak etme isteği uyandırmalıdır (Kavi, 2003). Yaya bölgeleri için toplu taşıma olanakları ve mutlaka uygun kapasitede otopark alanları düşünülmelidir. Otopark alanları yaya bölgelerinin dıșında tutulmalı, girișleri ise yaya bölgelerine yakın noktalardan sağlanmalıdır (Çınar, 2007).

Yaya bölgeleri planlamalarında, insan faktörü çalışmanın ana amacı olmalıdır. Kullanıcıların alandan çok yönlü yararlanabilmesi için uygun ortamlar yaratılmalı, işlevler kazandırılmalıdır (Gündüz, 1991). Yaya bölgelerinde mümkün olduğunca fazla sayıda doğal peyzaj unsuruna yer verilmeli, yapay ve doğal öğeler arasında bütünlük kurulmalıdır. Kullanım amacı ve isslevlerine uygun, kullanıcıların istek ve ihtiyaçlarına cevap verebilecek ve teknik alt yapıya sahip donatı elemanları tercih edilmelidir (Ökten ve Sancar, 2004). Yaya bölgelerinde, yaya bir noktadan diğerine güvenli ve en kısa yoldan ulaşmalı, en uzun mesafe 1 km'yi aşmamalıdır (Çınar, 2007). Yaya yolları, hareketi kolaylaştırmalı, kullanicilar tarafindan kolay benimsenebilmelidir. Yayayı yönlendirecek 
mekânsal düzenlemelere gidilmelidir. Yaya yollarının genişliği, yolun kullanılma amacına ve kullanım yoğunluğuna bağlı olarak değişir (Ökten ve Sancar, 2004). Yaya bölgelerinde, merdiven kullanımının zorunlu olduğu durumlarda merdiven kullanımının yanına rampalı çözümler geliştirilmelidir (Pakdil, 2001). Engellilerinde gereksinimleri göz önüne alınmalıdır. Yaya bölgelerinde, yayaları sıcak, soğuk, rüzgâr, yağmur, kar vb. hava koşullarında korumak için arkadlar, kapalı çarşılar, kapalı avlular yapılmalıdır (Kuntay, 2008). Yaya bölgelerinde yeterli kalitede yer döșemesi seçilmeli ve uygulanmalıdır. Aydınlatma yeterli düzeyde olmalıdır. Özgün ve nitelikli donatı elemanları bulunmalıdır. İlgi çekici su ögeleri ve plastik elemanlara, oturma mekânlarına yer verilmelidir. Yaya bölgesini yaşatacak eğlence, kültür, spor, sanat etkinliklerine olanak verecek mekânlar oluşturulmalıdır (Biriş̧̧i vd., 2002). Ayrıca yaya bölgesinde kullanılacak bitki türleri, ortamın ekolojik koşullarına, kullanıcı isteklerine ve kullanım işlevlerine bağlı olarak seçilmelidir (Çınar, 2007).

\section{Materyal ve Metot}

$\mathrm{Bu}$ çalışmanın amacı, Antalya kentinde bulunan Cumhuriyet Caddesi'ndeki planlama ve tasarım uygulamalarının ne ölçüde başarılı olduğu, çevresi ile etkileşimi, kullanım amaçları, kullanıcıların ihtiyaçlarına ne ölçüde cevap verebildiği, temel sorunlar, genel eksikliklerinin belirlenmesi ve sorunlara ilişkin çözüm önerilerinin getirilmesidir.

Araştırma Alanı kent merkezi içinde; Yaya mekânlarının araç trafiğinden ayrılması, Kentin kültürel ve rekreasyonel aktivitelerinin bu alanda gerçekleştirilmesi, Kentin en önemli ulaşım aksı olması, Tarihi yapıları alanda barındırması, Diğer ulaşım aksları ile kesişen toplanma ve dağılma noktalarına sahip olması özellikleri ile önem taşımaktadır.

Çalışma alanının doğal ve kültürel özelliklerinin saptanmasında, alanda doğrudan yapılan inceleme ve gözlemlerden, çekilen fotoğraflardan yararlanılmıştır.

Yapılan çalışmalarla araştırma alanının mevcut durumları arazi çalışmaları ve fotoğraflarla tespit edilmiştir. Araştırmada gözlem ve analizlerin yanı sira 100 kullanıcıya anket çalıșması uygulanmıștır. Yapılan anketler SPSS programı ile analiz edilerek irdelenmiştir. Analiz sonuçları doğrultusunda sorunlar ve eksiklikler belirlenmiş ve bunlara ilişkin çözüm önerileri ortaya konulmuştur.

\section{Bulgular}

Belirlenen amaçlar doğrultusunda, Araştırma Alanının konumu, mevcut yapıları ve alanı kullanan kent halkı ile yapılan görüşmeler değerlendirilmiştir.

Konumu: Antalya kenti, Türkiye'nin en kalabalık beşinci şehridir. 2014 itibarıyla 2.222.562 kişilik nüfusa sahiptir (URL-1, 2016). Antalya'nın merkezinde Kaleiçi ve yat limanının hemen üst kısmında yer alan Cumhuriyet Caddesi Çalıșma Alanı olarak seçilmiştir.

Cumhuriyet Caddesi, 2008 y1lında taşit trafiğine tamamen kapatılmıştır. Cumhuriyet Caddesi'ne Kuzeybatı'da Valilik, Güneybatı'da Yat Limanı, Güney de Kaleiçi, Doğu'da Atatürk Caddesi ve Kuzeydoğu da Ali Çetinkaya Caddesi üzerinden ulaşabilmektedir (Şekil 1).

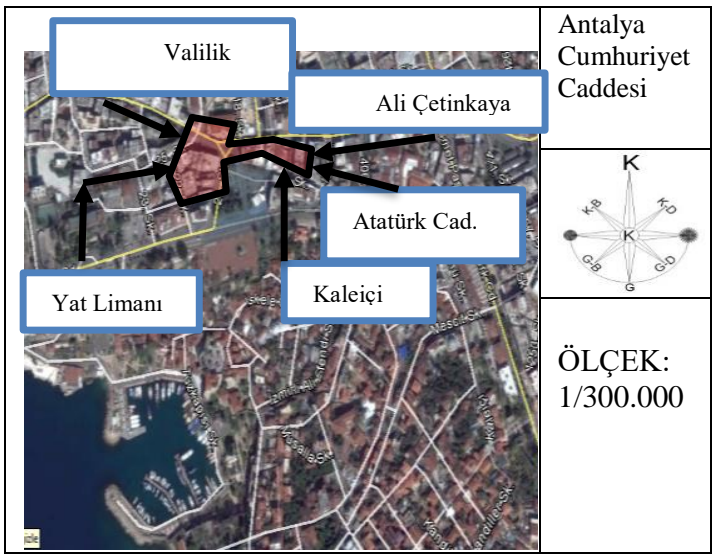

Şekil 1. Cumhuriyet caddesine ulaşım aksları (Google Earth'den uyarlanılmıştır)

Cumhuriyet Caddesinde, tarihi niteliğe sahip Cumhuriyet Meydan1, Yivli Minare Cami ve Külliyesi, Saat Kulesi, Tekeli Mehmet Paşa Cami yer almaktadır. Yaya bölgesi boyunca birçok mağaza, büro, eczane vb. dükkânlar bulunmaktadır (Şekil 2). Cumhuriyet Caddesi girişinde bir kapalı otopark mevcuttur (Şekil 3). Cadde içerisinden nostaljik tramvay hattı geçmekte (Şekil 4) ve faytonlar (Şekil 5) bulunmaktadır. 


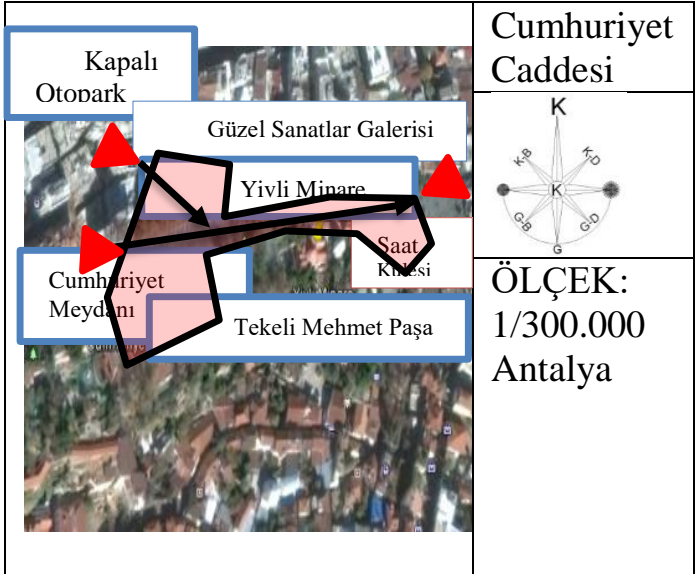

Şekil 2. Cumhuriyet Caddesi (Google Earth'den uyarlanılmıştır

Antalya'ya ismini veren II. Attalos'un Heykeli de (Şekil 6) burada yer almaktadır. Helenistik dönemde Bergama Kralı II. Attalos (MÖ 159-138), askerlerine "Gidin ve bana yeryüzündeki cenneti bulun." der.

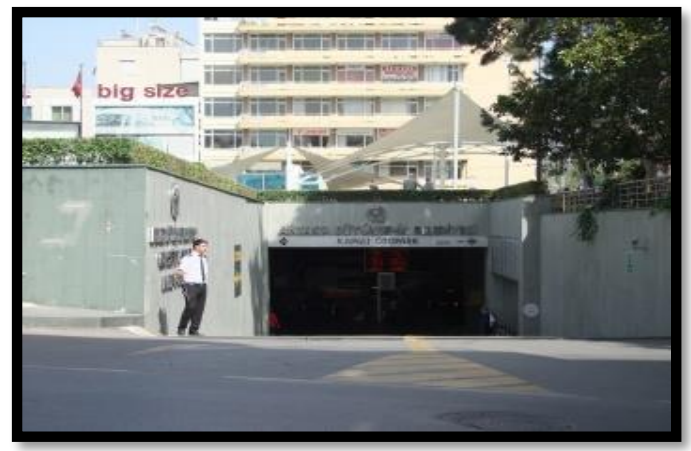

Şekil 3. Kapalı otopark

Askerlerinin gösterdiği yeri beğenen II. Attalos, bölgenin stratejik önemini dikkate alarak buraya bir liman şehri kurdurur ve Attalos'un adına binaen "Ataleia" olarak adlandırılır. Yerleşme, 20. yüzyılın ilk çeyreğinden başlayarak "Antalya" olarak adlandırılmıştır (URL-2, 2016).

Cadde boyunca oturma alanları, çeşmeler, 1şıklı su gösteri havuzları, yeşil alanlar yeralmaktadır (Şekil 7).

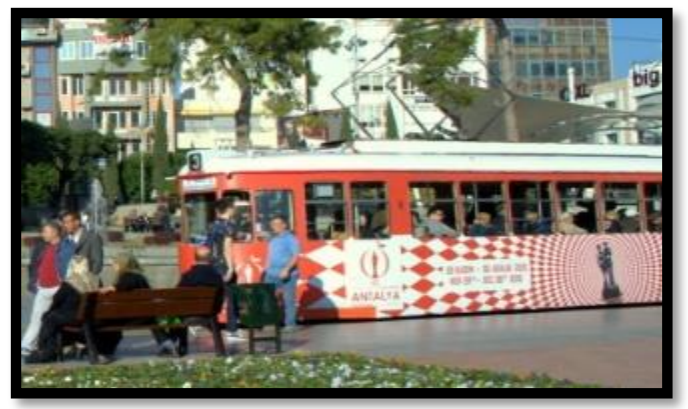

Şekil 4. Nostaljik tramvay hattı

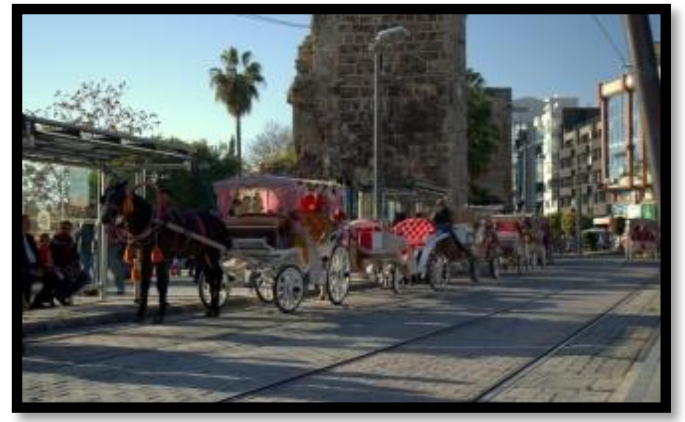

Şekil 5. Fayton kullanımı

\section{Mevcut yapılar:}

Cumhuriyet Meydanı: Cumhuriyet meydanı 8000 metrekarelik bir alanı kapsamaktadır. Cumhuriyet Meydanı'ndaki "Ulusal Yükseliş Anıtı" 1964 yılında açılmıştır (Şekil 8). Heykeltıraş Prof. Dr. H. Gezer tarafindan yapılan ve bedeli Antalya halkından toplanan bağışlarla karşılanan bu heykel, anit heykelciliğine bir yenilik getirmiştir. Kaidedeki dik yüzeylere İstiklal Savaşı'nın çeşitli evrelerinin adı yazılmaya çalışılmış, ancak tamamlanamamıştır (Çimrin, 2006).

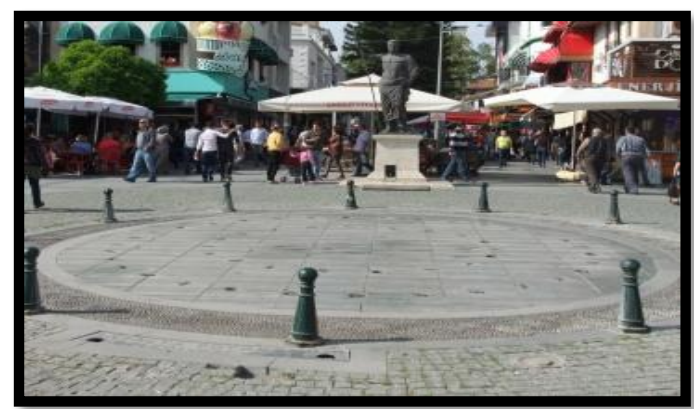

Şekil 6. Attalos heykeli

Yivli Minare Cami ve Külliyesi: Yivli Minare, Kaleiçi'nde, İskele Caddesi Tabakhane Sokak'ta, Vakıflar mülkiyetindeki 
kendi adı ile anılan külliye içerisinde yer almaktadır (Şekil 9) (Anonim 1). Minare etrafında şekillenen Yivli Minare Külliyesi farklı kotlarda teraslanmış eğimli bir arazide yer almaktadır. Külliyenin ana yapısı Yivli Minare ve Alaeddin Cami ya da Ulu Cami olarak da bilinen Yivli Minare Cami'dir (Avc1,2015). Yivli Minare, XIII. yüzyıla ait bir Selçuklu eseridir. Yüksekliği $38 \mathrm{~m}$. olup 90 basamaklı bir merdiven ile çkılan 8 yivli minare, günümüzde Antalya kentinin sembolü durumuna gelmiştir. (URL-3, 2016).

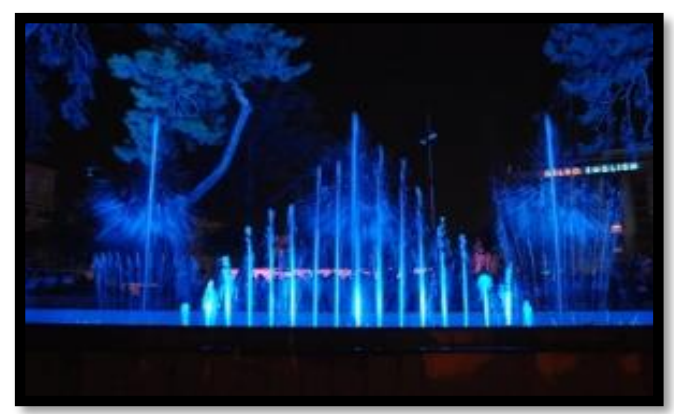

Şekil 7. Su gösteri havuzu

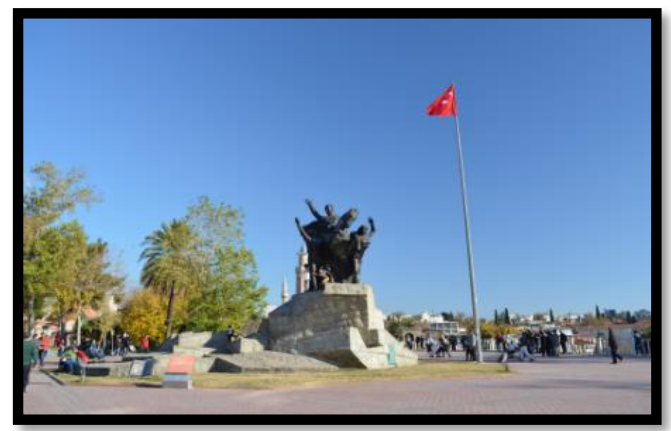

Şekil 8. Meydanda yer alan anıt

Saat Kulesi: Șehrin merkezinde, kale kap1s1 mevkiinde yer alan Saat Kulesinin (Sekil 10), kim tarafindan ve ne zaman yapıldığı bilinmemektedir. II. Abdülhamid döneminde yapılmış olabileceği tahmin edilmektedir (Riefstahl, 1941). Günümüzde eski saat mekanizması yerine, elektronik saat takılarak yenilenmiştir. Eski saat mekanizmasından sadece çanı kalmıştır.

Tekeli Mehmet Pașa Camii: Antalya Kalesi girişinde ve Saat Kulesi'nin arkasında yer alan bir Osmanlı eseridir (Şekil 11). Daha önce mevcut başka bir binanın 17. yüzyılda tekrar elden geçirilerek bugünkü halini aldığ iddia edilmiş; hatta 18.yüzyılda
Mevlevihane'yi tekke haline getiren kișinin Tekeli Mehmet Paşa olduğu varsayımı ile caminin şimdiki adını da ancak bu yüzyıldan sonra aldığı öne sürülmüştür (Yılmaz, 2002).

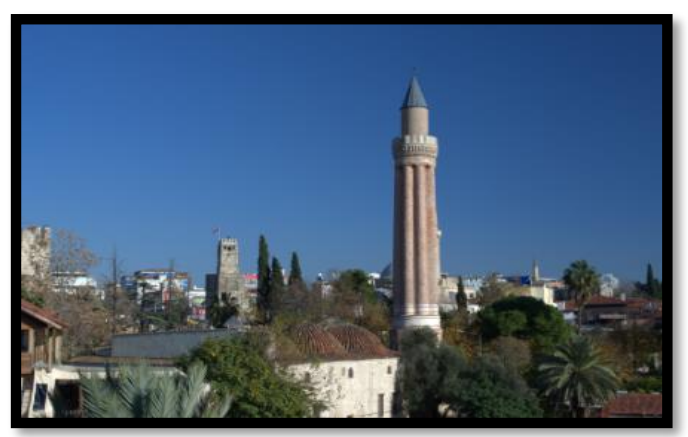

Şekil 9. Yivli Minare Cami ve Külliyesi

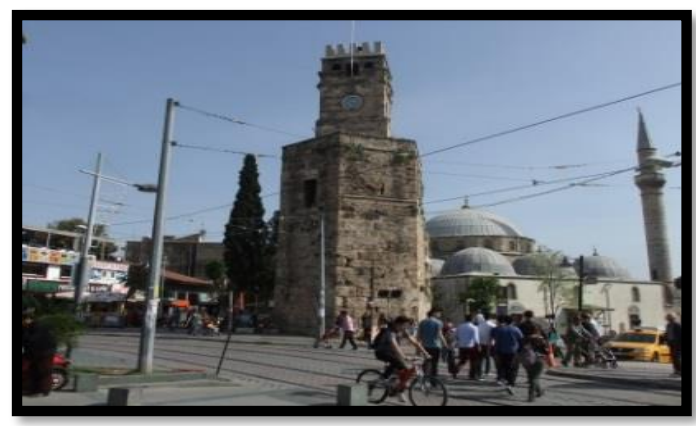

Şekil 10. Saat Kulesi

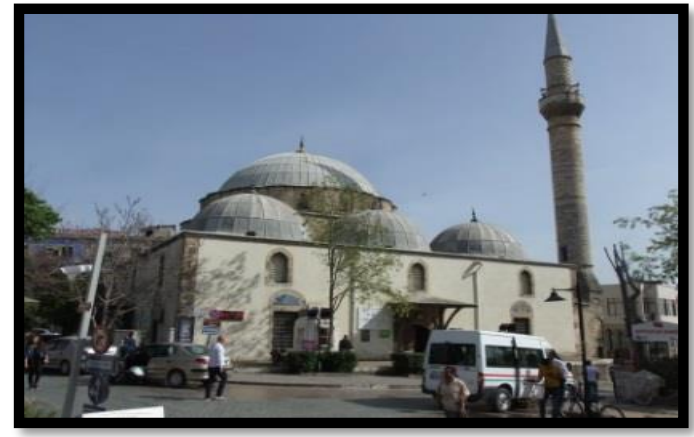

Şekil 11. Tekeli Mehmet Paşa Cami

Güzel Sanatlar Galerisi: Cumhuriyet Meydanında bulunan tarihi Mevlevihane binasında uzun yıllar sanata ve sanatçıya hizmet sunduktan sonra Mevlevihane binasının büyük çaplı bir onarıma ihtiyaç olduğunun tespit edilmesi ve 2014 y1l başlarında kapsamlı bir tadilata alınması nedeniyle yeni bir Galeri hizmet binası arayıșı sonucunda Güzel Sanatlar Galerisi olarak hizmet vermesi amaciyla 44 sanatçının 59 
eseriyle resmi açılışı yapılarak halen burada faaliyetini sürdürmektedir (URL 4, 2016).

\section{Kent halkı ile yapılan anket çalışmasına ilişkin bulgular}

Araştırma alanı olarak seçilen Cumhuriyet Caddesinin yayalar tarafindan güncel kullanımlarının saptanması, kullanıcı özelliklerinin ve eğilimlerinin belirlenmesi, alanın tercih edilme nedenleri, kullanım amaçları, kullanıcıların ihtiyaçlarına ne ölçüde cevap verebildiği, alanın yaşamakta olduğu temel sorunlar ve planlamasındaki genel eksiklikler ve/veya yeterliliklerin belirlenmesi amaciyla 100 kullanıciya anket çalışması uygulanmıştır. Anket çalışmasının ilk bölümünde, Cumhuriyet Caddesi'nin kullanım özelliklerinin belirlenmesine yönelik sorular yöneltilmiştir. Sonuca göre; anket yapılan kişilerin cumhuriyet caddesine ziyaret sıklığının dağılımı; \%29'u ayda birkaç kez, \%29'ü hergün, \%16's1 haftada bir, $\% 12$ 'si ayda bir, \%11'i haftada birkaç kez ve \%3'ü nadiren olduğu görülmüştür (Şekil 12). Anket sonuçları doğrultusunda; Cumhuriyet Caddesinin kullanıldığı aylara bakıldığında, kullanıcıların \%52'si için fark etmediğini, $\% 35$ 'inin ise her mevsim, diğer \%13 lük bir dilimin ise tüm aylara dağılarak kullanıldığ görülmektedir (Şekil 13). Anket sonucuna göre Cumhuriyet caddesini kullanan kullanıcıların \%50' si gün olarak değişken, $\% 37$ 'si hafta sonu, \%8'i hafta içi, \%5'i her zaman kullanıyor olduğunu belirtmiştir (Şekil 14). Cumhuriyet Caddesini; kullaniciların \%40'1 buluşma yeri olarak, \%37'si tarihi turistik niteliği, \%36'sı içerdiği fonksiyonlar, $\% 30$ 'u nedensiz rastlantı, \%25'i alışkanlık, \%15'i dini mekânlar, \%10'u yakınlık, \%5'i diğer ve \%1'i tavsiye üzerine tercih ettiklerini belirtmişlerdir (Şekil 15).

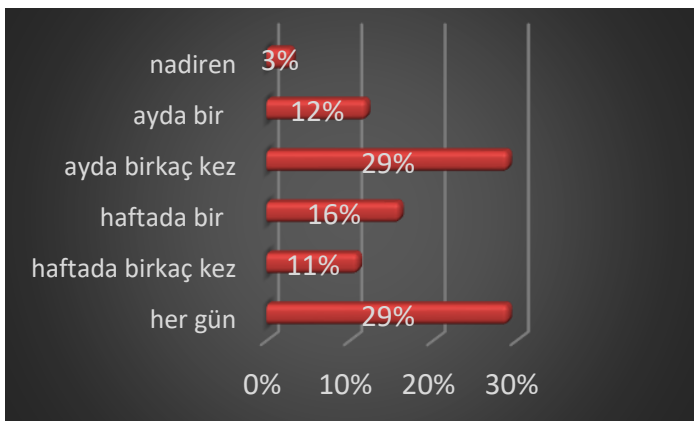

Şekil 12. Alanın ziyaret edilme sıklığı
Antalya Kenti'ndeki Cumhuriyet Caddesi Yaya Bölgesi, barındırdığı eski ve yeni kent dokusu ile bu doku içerisinde yer alan ticaret alanları yayalar açısından bir çekim merkezi ve geçiş arteridir.

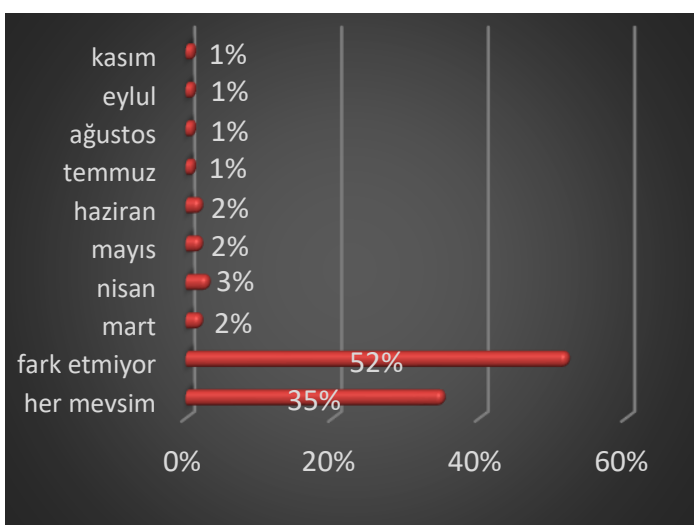

Şekil 13. Alanının aylara göre kullanımı

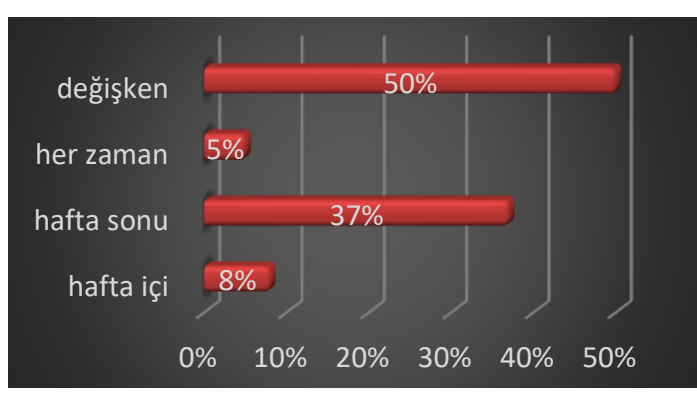

Şekil 14. Alanının günlere göre kullanımı

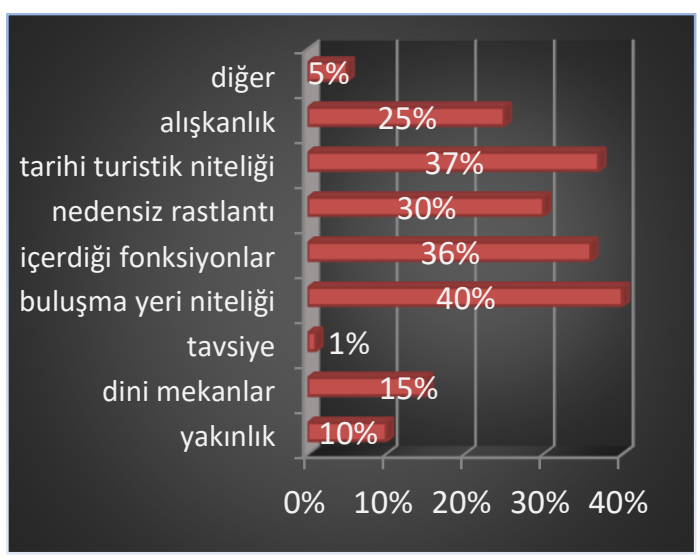

Şekil 15. Alanının tercih edilme nedeni

Araştırma alanında çok sayıda mağaza, işyeri, dükkân, banka ve büro gibi kullanımlar mevcuttur. Anket sonuçlarına göre alanda yapılan etkinliklerin dağılımı; \%56'sı geçiş, $\% 49$ 'u gezme inceleme, \%41'i seyir, \%33'ü sohbet sosyalleşme, \%29'u oturma, \%27'si yeme içme, $\% 21$ 'i alışveriş, \%20'si bekleme, $\% 17$ 'si fotoğraf çekme, \%16's1 dinlenme 
uzanma, \%15'i ibadet etme, \%8'i diğer, \%7'si müzik dinleme ve \%1'i okuma olarak görülmüştür (Şekil 16).

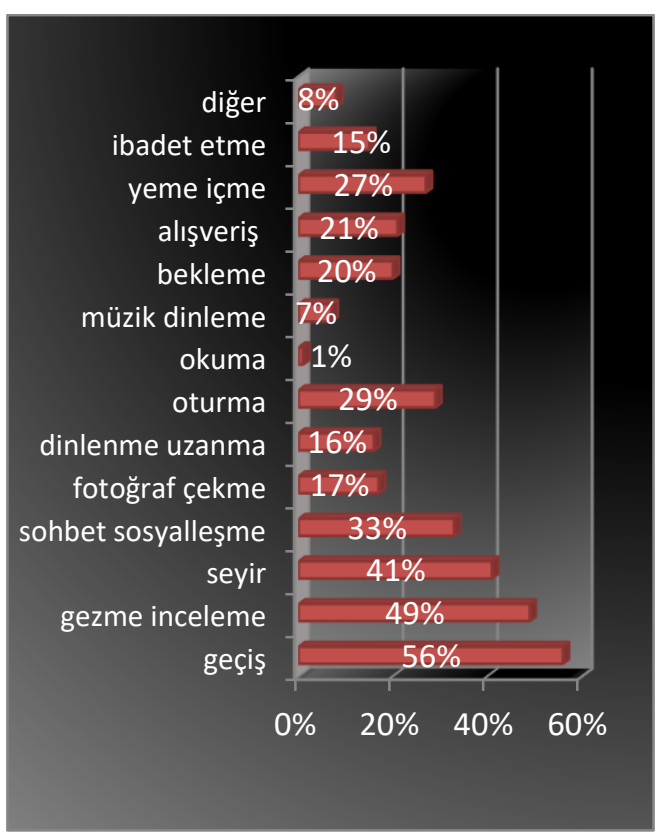

Şekil 16. Yapılan etkinliklerin dağılımı

Anket sonuçlarına göre; kullanıcılar Cumhuriyet Caddesi'nde tahmini kalış sürelerini; \%39'u 1-2 saat, \%34'ü 10 dakika1 saat, \%13'ü 2-4 saat, \%12'si 1-10 dakika, $\% 2$ 'si ise 4-6 saat olarak belirtmişlerdir (Şekil 17). Anket yapılan kişilerin \%48'i Cumhuriyet Caddesindeki kullanımlar ve fonksiyonları yeterli görürken, \%52'si yeterli görmemektedir (Sekil 18). Ankete katılan kullanıcıların, Cumhuriyet Caddesi'nde olmasını istedikleri fonksiyonların dağılımı; \%40'1 dinlenme alanı, \%30'u yeşil alan, \%30'u açık hava gösteri alanı, \%19'u açık hava sergi alan1, \%18'i otopark, \%7'si su öğesi/oyunu, \%4'ü çocuk oyun alanı, \%4'ü restoran/kafeterya, \%3'ü ışı oyunu, \%3'ü çok amaçlı merkez, \%2'si diğer ve \%2'si spor alanı olduğu görülmüştür (Şekil 19).

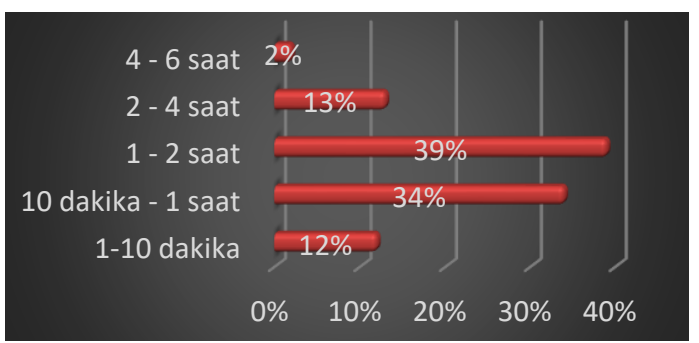

Şekil 17. Kullanıcıların tahmini kalış süreleri
Cumhuriyet Caddesi'nde bulunan açık ve yeşil alanlar yeterli mi, kullanış ve yer açısından uygun mu sorusuna \%42'si yeşil alanların yetersiz ve uygun olmadığı, \%33'ü yetersiz-uygun olduğu, \%20'si yeterli- uygun olduğu, \%5'i ise yeterli fakat uygun olmadığ cevabını vermiştir (Şekil 20). Ankete katılan kişiler; Cumhuriyet Caddesi'nde bulunan kentsel mobilyalar (bank, çöp kutusu vs.) yeterli mi, kullanış ve yer açısından uygun mu sorusuna \%48'si kentsel mobilyalarının yetersiz ve uygun olmadığ 1 , \%27'si yetersizuygun olduğu, \%20'si yeterli- uygun olduğu, $\% 5$ ' $\mathrm{i}$ ise yeterli fakat uygun olmadığı cevabını vermiştir (Şekil 21).

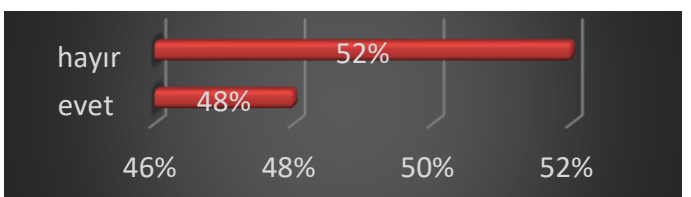

Şekil 18. Alanın kullanım ve fonksiyonlar açısından yeterliliği

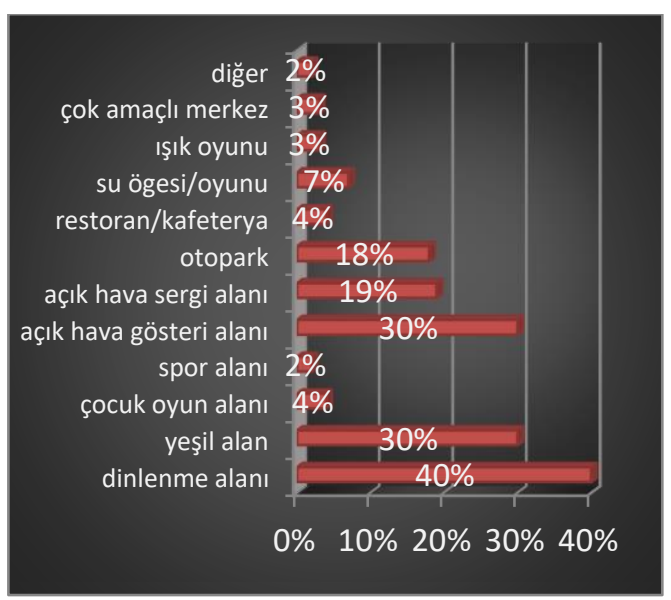

Şekil 19. Alanda istenilen fonksiyonlar

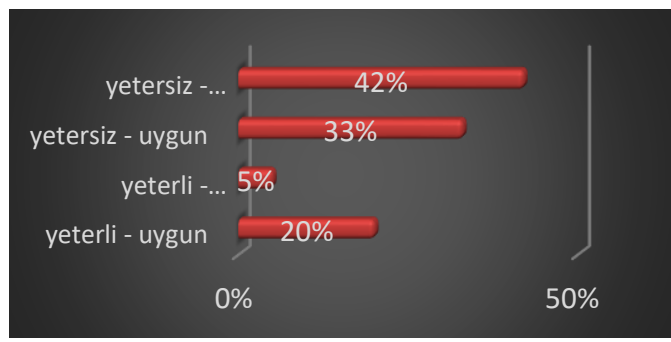

Şekil 20. Alanda yeşil alanların yeterliliği

Kullanıcılara Cumhuriyet Caddesi'nde yetersiz ve kullanım açısından yanlış bulunan donatıların ne olduğu sorulmuştur. \%80'i alanda bulunan bankları yetersiz ve kullanım 
açısından yanlış bulmuştur. Bunun yanı sıra kullanıcıların \%60'1 gölgelik ve aydınlatma elemanları, \%54'ü çiçeklik, \%50'si döşeme kaplamaları, \%40'1 anıt, heykel, sanatsal ögeleri, \%40'1 bisiklet yolu, \%26's1 reklam panolarını yetersiz bulmuştur. \%21'i çeşme, $\% 17$ 'si durak, \%15'i çöp kutusu, \%15'i büfe/satış birimleri, \%15'i bankamatikler, \%14'ü bina/vitrin/dükkân cepheleri, \%13'ü tabelalar/işaret levhaları, \%13'ü WC, \%9'u bariyerler/sınırlayıcılar, \%9'u posta kutusu, $\% 8$ 'i su oyunları, \%2'si saati yetersiz ve kullanım açısından yanlış bulmuştur (Şekil 22).

Anket çalışmasının üçüncü bölümünde kullanıcilara Cumhuriyet Caddesi'nin ulaşımına yönelik sorular yöneltilmiştir. Anket yapılan kişilerin \%35'i Cumhuriyet Caddesi'nin çevresiyle ulaşılabilirliğini yeterli görmezken $\% 65{ }^{\prime} i$ ise yeterli görmektedir. Kullanıcıların Cumhuriyet Caddesi'ne gelirken tercih ettikleri ulaşım araçlarının dağılımı; \%40'1 otobüs, \%38'i yaya $\% 37$ 'si otomobil, $\% 20$ 'si tramvay, $\% 6$ 's1 taksi, \%5'i bisiklet, \%4'ünün ise motosiklet olduğunu belirtmişlerdir(Şekil 23). Anket uygulanan kişilerin \% 70 'ine göre alana girișin belirgin ve yeterli olduğu, \%30'una göre ise alana giriş noktaları belirgin ve yeterli olmadığı sonucuna varılmıştır.

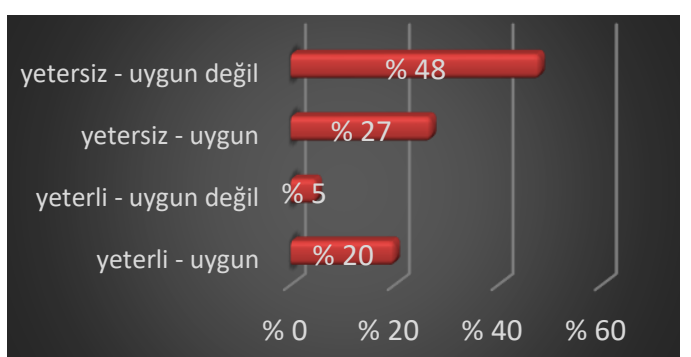

Şekil 21. Alanda kentsel mobilya yeterliliği

Anket yapılan kişilere ulaşımla ilgili problemlerin neler olduğu sorulduğunda alınan cevaplara göre; \%64'ü yoğun taşıt trafiğinin olması, \%50'si otopark alanının

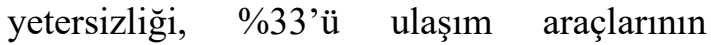
kalabalıklığı, \%30'u durak yerinin yanlış olması, \%17'si yoğun yaya trafiğinin olması, $\% 16$ 'sı ulaşım araçları yetersiz olması, \%11'i döşemelerin bozukluğu, \%11'i yönlendirme yetersizliği, \%3'ünün ise diğer niteliğinde olduğu görülmüştür (Şekil 24). Güzergâhın, kent merkezinin yolcu ve araç yükünü taşıyan önemli caddelerden biri olması cadde girişinde yolun kenarları ve kaldırımlar araçlar tarafından işgal edilmesi, hem yaya hem de araç trafik akışını büyük ölçüde engellemektedir.

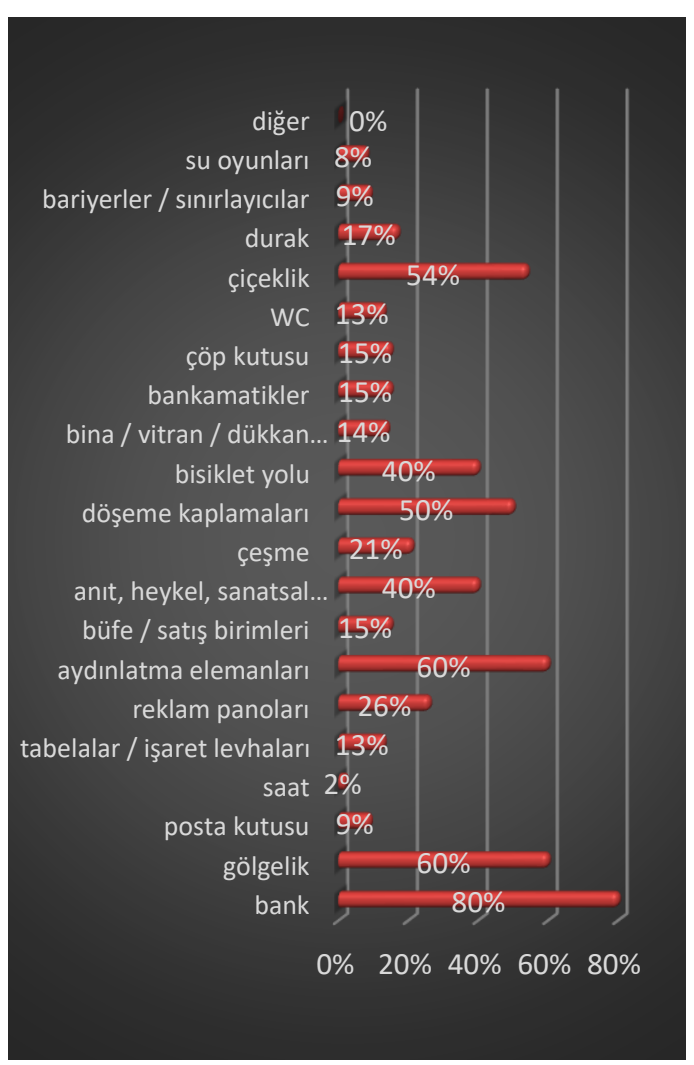

Şekil 22. Kullanıcıların yetersiz ve kullanım açısından yanlış bulduğu donatılar

Anket çalışmasının dördüncü bölümünde anket yapılan kişilere Cumhuriyet Caddesi'nin imaj1 hakkında sorular yöneltilmiştir. Anket çalışmasında kişilerin \%40'1 Cumhuriyet Caddesi'nin genel durumundan memnunken, \%60'ının memnun olmadığı görülmüştür (Şekil 25).

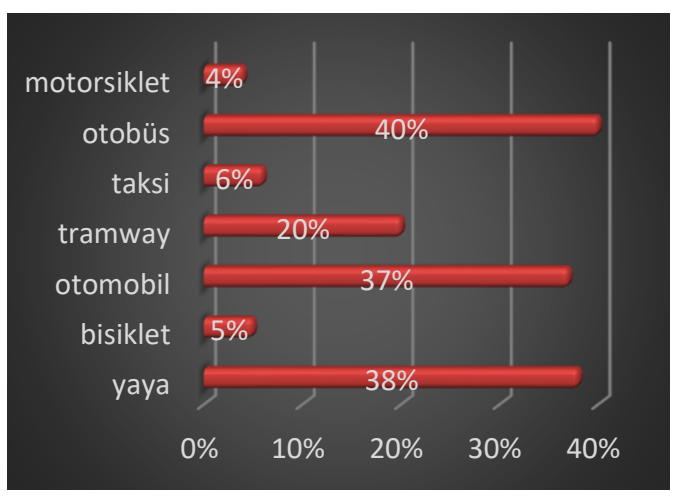

Şekil 23. Kullanılan ulaşım araçları 
Kullanicilarin \%24'ü Cumhuriyet Caddesi'nin fiziksel kurgusu ile sağladığ aktiviteler mekânın tarihi yapısı ile örtüştüğünü düşünmekte, \%74'ünün ise örtüşmediğini düşünmektedir (Şekil 26). Alanda kullanıcıları rahatsız eden unsurların dağılımı; \%48'i seyyar satıcılar, \%46's1 engelli düzenlemelerin eksikliği, \%46's1 ulaşım sorunu-trafik, \%31'i gürültü, \%23'ü kalabalık, \%23'ü kirlilik, \%7'si vandalizm, \%6'sının ise diğer olduğu görülmüştür (Şekil 27). Çalışma alanının içinde barındırdığı tarihi doku ile uyumsuz olduğu kullanıcılar tarafından da belirtilmiştir.

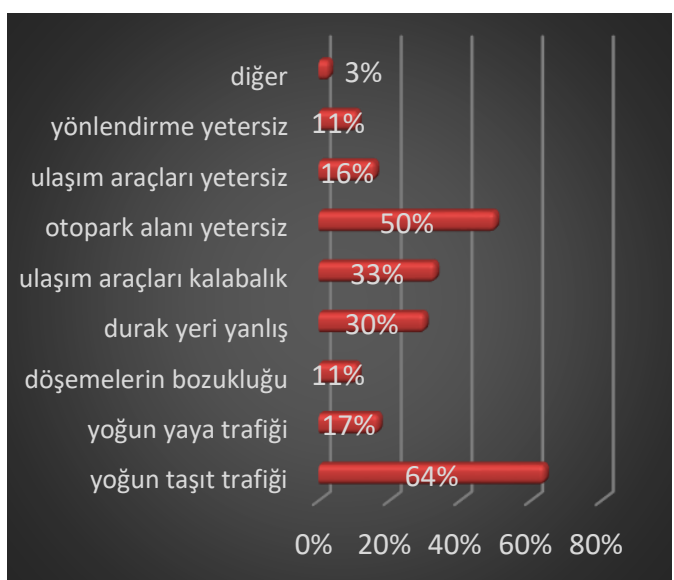

Şekil 24. Alandaki ulaşım problemleri

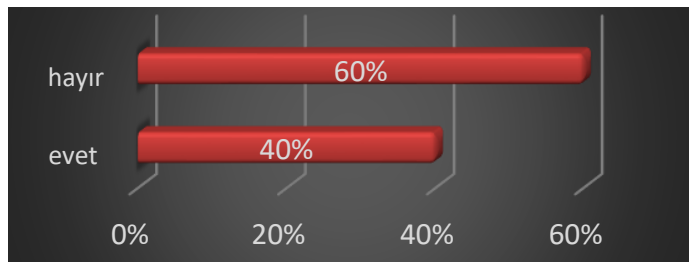

Şekil 25. Genel durumdan memnunluğu

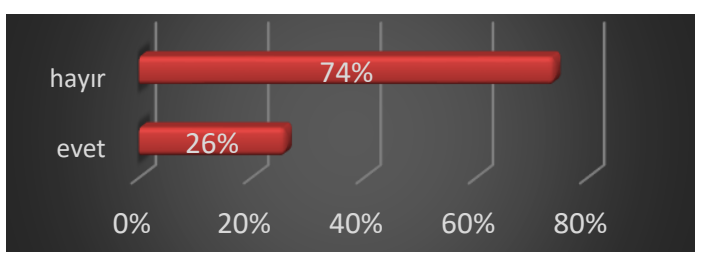

Şekil 26. Alan tarihi yapısı ile uyumu

Anket çalışmasının son bölümünde ise kullanıcı özelliklerine yönelik sorular yöneltilmiştir. Ankete katılan 100 kişiden $\% 47$ 'si bayan, \%53'ü ise erkektir. Yaşları ise; $\% 5$ 'i 18 yaş altı, \%45'i 18-30 yaş arası, \%37'si 31-45 yaş aras1, \%12'si 46-60 yaş arası, \%1'i ise 61-75 yaş arasıdır (Şekil 28). Ankete katılanların eğitim durumu; \%3'ü ilkokul mezunu, \%3'ü ortaokul mezunu, $\% 43$ 'ü lise mezunu, \%47'si üniversite mezunu, \%3'ü yüksek lisans mezunu ve $\% 1$ 'inin diğer olduğu belirtilmiştir.

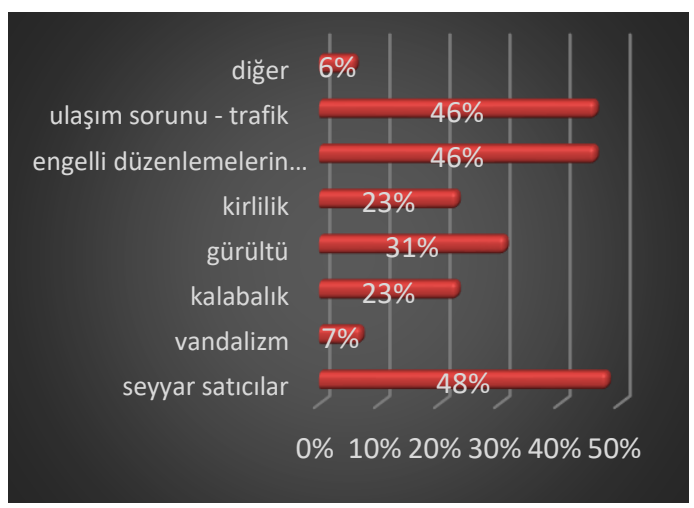

Şekil 27. Alanda kullanıcıları rahatsız eden unsurlar

Ankete katılan kişilerin meslekleri değerlendirildiğinde; \%16's1 öğrenci, \%15'i turizm, \%8'i mühendis, \%8'i peyzaj mimarı, $\% 7$ 'si iş güvenliği uzmanı, \%7'si satış temsilcisi, \%5'i finans, \%5'i tekniker, \%4'ü emekli, \%4'ü ev hanımı, \%3'ü esnaf, \%3'ü muhasebe, \%2'si müzisyen, \%2'si insan kaynakları, \%2'si bilgi işlem, \%2'si memur, $\% 2$ 'si hemşire, \%2'si doktor, \%2'si öğretmen, $\% 1$ 'i çiftçi olarak belirlenmiştir (Şekil 29). Ankete katılan kişilerin gelir dağılımı da ; \%24'ü 0-1000 TL arasında, \%59'u 1001-3000 TL arasinda, \%10'u 3001-5000 arasinda, $\% 7$ 'si ise 5000 TL'den fazla olarak saptanmıştır.

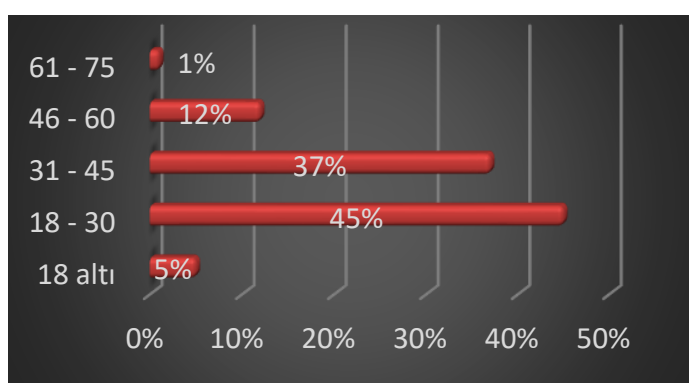

Şekil 28. Katılımcıların yaş aralığı

Farklı meslek grupları ve farklı gelir düzeyine sahip kullanıcıların varlığının nedeni, farklı işlevlerde kullanımları olan işyerleri ve önemli yapıları ile kullanıcıların 
en çok kullandıkları güzergah olması ve Antalya'nın en işlek caddesinden biri olmasından kaynaklanmaktadır.

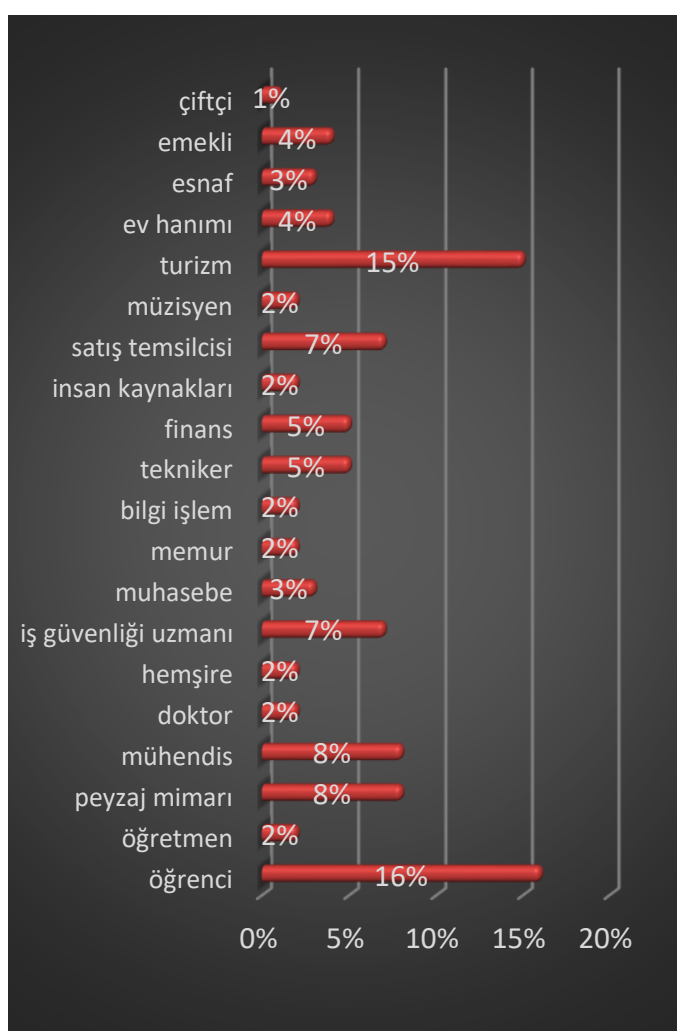

Şekil 29. Katılımcıların mesleği

\section{Tartışma ve Sonuç}

Kent içinde kentlinin yaşanabilirliğini arttıran, sosyal ve kültürel aktivitelerini sürdürebilecekleri, kentin kimliğini koruyan, kolay erişilebilir, güvenli, kentsel planlama ve tasarım ilkelerine uygun, toz ve gürültü kirliliğinden uzak, yaya ile dost alanların planlama ihtiyacı gün geçtikçe artmaktadır. Son yıllarda ülkemizde yayalaştırma çalışmalarının arttığı, fakat yapılan yaya öncelikli alanlarda alınan yanlış kararlar, çevre ile uyumsuzluklar, getirilen çözümlerde eksikler olduğu görülmektedir.

Araştırma alanı olarak seçilen Antalya kent merkezindeki Cumhuriyet Caddesi, birçok tarihi dokuyu içinde barındıran, ticari potansiyeli yüksek, yoğun kullanım içeren, 318 metre uzunluğunda bir yaya bölgesidir. Çalışma alanı olarak seçilen yayalaştırılmış alanda yapilan mevcut durum analizi ile sosyal, kültürel, estetik ve ekonomik açıdan daha iyi bir sonuç nasıl çıkartılır sorusuna cevap aranmıştır. Anket çalışmasından elde edilen verilere göre ise; ziyaretçiler tarafindan alanda çevre ulaşılabilirliği, alan içi ulaşılabilirlik ve giriş noktaları algılanabilir fakat çok yoğun bulunmuştur. Alan girişinde bulunan ulaşım araçlarında ki yoğunluk da sorun olarak tespit edilmiştir. Günümüz kentlerinin en önemli sorunu, taşıt trafiğgi ve otopark sorunudur. Alanda 19 otobüs, 76 binek otomobil kapasiteli bir kapalı otopark mevcuttur. Yapılan anket çalışmalarında çıkan sonuç doğrultusunda otopark alanının yetersiz olduğu saptanmıştır. Çevredeki otopark alanlarının ivedilikle artırılması gereklidir. Cumhuriyet caddesi taşıt trafiğine kapalı olmasına rağmen, caddenin giriş çıkışları yoğun taşıt trafiğine maruz kalmaktadır. Cumhuriyet caddesinin giriş kısmında yer alan otobüs durağı ve alan girişinde duran tur otobüsleri zaten sıkışık olan trafiğin daha da artmasına neden olmaktadır. Toplu taşıma araçları ve tur otobüslerinin durak noktalarının yerini değiştirerek trafiğin yoğunluğunun azaltılması sağlanmalıdır. Elde edilen veriler doğrultusunda; gerek yeşil alanların, dinlenme alanların ve kentsel mobilyaların yetersiz olduğu görülmüştür. Kullanıcıların yaya bölgesinde daha fazla zaman geçirmeleri ve dinlenmelerine olanak sağlayacak oturma mekânları yaratılmalı, yeşil alan düzenlemeleri arttırılmalı, alanda bulunan kentsel mobilyalar ve döşemelerde iyileştirmeler yapılmalıdır. Tam merkezde yer alan saat kulesi, odak niteliği taşıdığından döşeme ile vurgulanması, Güzel sanatlar galerisi önünde açık sergi alanlarına yer verilmesi, Cumhuriyet meydanının tekrar revize edilerek caddenin daha estetik bir görünüme kavuşturulması sağlanmalıdır. Görsel kirliliğe neden olan reklâm levhaları, kent mobilyaları, aydınlatma elemanları ve satış alanları arasında malzeme ve doku uyumu sağlanarak birbirleriyle ve tarihi çevreyle uyumlu görsel bir bütünlük sağlanmalı ve alan tarihi dokusunu yansıtmalıdır. Engelsiz ulaş1labilirliğin eksikliği de tasarım sorunlardan bir tanesidir. Tüm alanda engelsiz ulaşılabilirliği sağlayacak düzenlemeler yapılmalıdır. Alanda rahatsiz eden unsurlardan biride alanda dağınık, düzensiz olan seyyar satıcıların varlığıdır. Seyyar satıcılar için gerek görsel ve gerekse tarihi alana uyum 
sağlayan nitelikte alanların oluşturulması gerekmektedir. Büyükşehir Belediyesi Cumhuriyet Caddesi ve içerisinde bulunan Cumhuriyet Meydanı için yeni bir düzenleme yapmayı planlamaktadır (Şekil 30, 31). Önerilen Projede, kent meydanı ve yakınındaki kent parkı bir araya gelebilecek şekilde ele alınmıştır. Alanın mevcut halinde yeşil alanların azlığı ve kent mobilyaların yetersizliğinden dolayı, önerilen projede kent mobilyalarında düzenlemeler yapılmış ve yeşil alanlar arttırılmıştır. Bu projenin temel amac1; bitki ve tarihi değerlerin korunması ve iyileştirilmesidir.

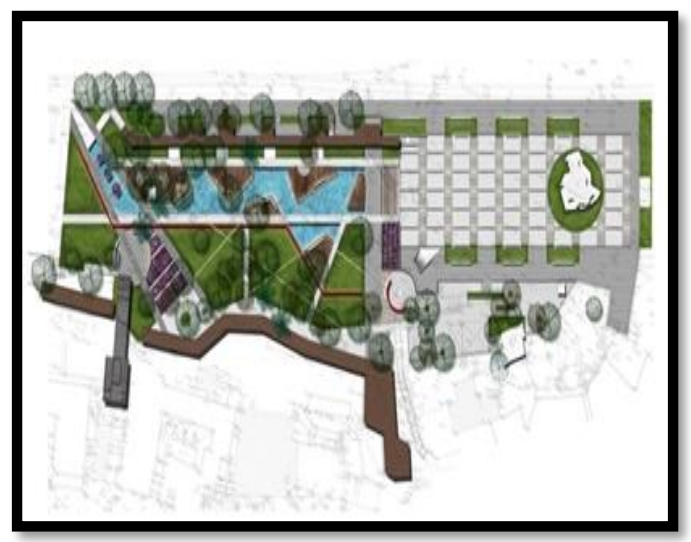

Şekil 30. Önerilen proje (URL - 5, 2016)

Proje tasarım ve uygulama aşamalarında sadece bu alanla değerlendirilmemeli, çevresiyle uyumu da göz önünde bulundurulmalıdır. Tarihi dokudan uzaklaşmış bir alan, kimliğini kaybetmeye mahkûmdur. Cumhuriyet Caddesi yeniden yapılandırılırken, kentlinin ihtiyaçları göz önünde bulundurularak kent halkının da planlama sürecine katılımın sağlandığı bir düzenleme yapılmalıdır. Özellikle ülkemizde yapılan çalışmalarda koruma bilincinin halen gelişmemesi, yerel yönetimlerin aldığı yanlış kararlar ve hatalı müdahaleler, tarihi dokunun bulunduğu alanlarda, alana uymayan tasarımların yapılması ve mekâna anlamsız işlevler yüklenmesi, bazı değerleri tamamen ortadan kaldırarak dokuyu yok etmeye neden olmaktadir.

$\mathrm{Bu}$ bağlamda, Tarihi kent merkezleri teknoloji çağının modernleşme çabaları sonucu, tarihi değerlere bağlılığın azalması sorunu karşısında bugün kimliğini kaybetmeye yüz tutmuş bir sürü örnekle karş1 karşıyadır. Doğru kararların alınabilmesi disiplinler arası bir çalışma gerektirirken, kuşkusuz en büyük görev de peyzaj mimarlarına düşmektedir.

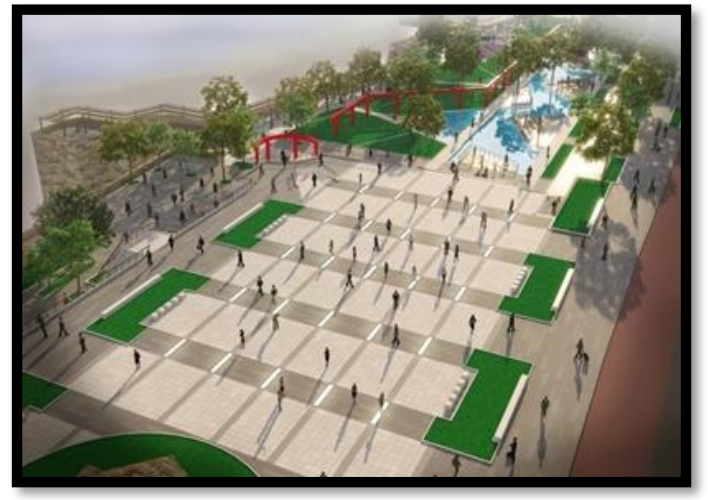

Şekil 31. Önerilen proje (URL - 5, 2016).

Yaya bölgeleri kentin karakterini belirleme yetisine sahiptir. Kim için ve hangi amaçla tasarlandığı anlaşılamayan alanlarda, kaliteden de uzaklaşılmaktadır. $\mathrm{Bu}$ yaklaşımla; mekânın öznesi olan kullanıcı dikkate alınmamaktadır.

Oysa kentsel mekânlarda insan gereksinimlerinin göz önüne alınması çok önemlidir (Gehl, 2010). Doğal ve kültürel değerleri korunmuş bir çevrede yaşamak mekanın kullanan her kullanıcının hakkıdır. Tarihi yapıları ve yüksek ticari potansiyeli ile önemli bir yaya bölgesi olan Cumhuriyet Caddesi, Antalya'nın kent kimliği ve kullanıcı istekleri ile uyumu dikkate alınarak işlevsel ve estetik gereksinimlere uygun olarak yeniden ele alınıp kente ve yayalara sunulmalıdır. Böylece Antalya'nın en prestijli mekânı olarak, mekânsal kalitesi yüksek bir yaya bölgesinin gelecek nesillere de miras olarak aktarılması da sağlanacaktır.

Unutulmamalıdır ki, çağdaş kentlerde, yaya her zaman üstün ve önceliklidir ve çağdaş kentsel mekânlar, kaliteli toplum oluşturmada önemli işlev gören alanlardır.

\section{Kaynaklar}

Anonim 1: Antalya Kültür Envanteri, Antalya: İl Özel İdaresi Kültür Yayınları 2004/1.

Aru, K.A., 1965. Yayalar-Taşıtlar: Şehir Dokusunda Yeni Ulaştırma Düzenleri, İ.T.Ü. Mimarlık Fak. Yayınları, İstanbul

Avc1, Ü., 2015. Süleyman Demirel Üniversitesi Güzel Sanatlar Fakültesi Hakemli 
Dergisi ART-E Mayıs-Haziran 15 Sayı:15 ISSN 1308-2698

Bayraktar, A., Aslanboğa, Ġ., Özkan, B., Güney, A. Ve Türkyılmaz, B; 1987. İzmir Kenti İçinde Halkın Açık Alan Gereksinimini Karşılamak Amacıyla Bazı Yol Ve Meydanların Taşı Trafiğinden Arındırılması Olanakları Üzerine Araştırmalar. E.Ü.Z.F. Peyzaj Mimarlığı Bölümü, Bornova.

Birişçi Yıldırım T., Özel, A. E. ve Oktay, P. 2002. Yaya Bölgeleri Planlama Ve Tasarımı: Çanakkale Çarşı Caddesi Yaya Yolu Örneğinde, Uluslararası Trafik ve Yol Güvenliği Kongresi'nde Sunulan Bildiri, Gazi Üniversitesi, Ankara.

Cebeci, Ö.F, Çakılcığlu M., 2001. Ulaşımda Gözden Kaçan Ayrıntı: Yaya. İstanbul'da Kentiçi Ulaşım Sempozyumu. TMMOB Makine Mühendisleri Odası, 28-29 Haziran, İstanbul.

Çınar, H.S.,2007, Yaya Bölgeleri Ve Meydan Tasarım İlkeleri, İ.Ü. Peyzaj Mimarlığı Lisansüstü Ders Notları, İstanbul.

Çimrin, H. 2006; Bir Zamanlar Antalya, Antalya Ticaret ve Sanayi Odası (ATSO).

Demir, S., 1999, Yaya Bölgelerinin Kent İçin Önemi, Kente Katkıları Ve Ankara'daki Yaya Bölgelerinin İrdelenmesi, Y. Lis Tezi, Ankara Üniversitesi, Fen Bilimleri Enst., Ankara.

Franc1s, M., 1991, TheMaking of Democratic Streets, Public Streets ForPublicUse, (Ed: A.V. Moudon), Part: 1-Page: 23-40, Columbia UniversityPress, New York, 0-231-07599-5.

Gehl J., 2010, Cities for People , ISBN 9781597265737,Washington

Gündüz, O., 1991, Kent Mekanlarının Yaşatılması, 1. Kamu Mekanları Tasarımı ve Kent Mobilyaları Sempozyumu, 15-16 Mayıs 1989, İstanbul, M.S.Ü. Matbaas1, 143-144.

Kavi, F., 2003, İstanbul'daki Yaya Yolu

Düzenlemelerinin Bitkisel Tasarım Açısından Değerlendirilmesi, Yüksek Lisans Tezi, İ.T.Ü. Fen

Bilimleri Enstitüsü, İstanbul

Kuntay, O. 1994. Yaya Mekanı. Ayıntap Yayıncilık. Ankara.

Kuntay, O. 2008. Yaya Mekanı. İlke Yayınevi. Ankara, 978-605-5983-08-6.

Ökten, N. Ve Sancar, C., 2004, Kentsel Donatılar-Ulaşım, Kentsel Alanların Planlanması ve Tasarımı, Akademi Kitabevi, Trabzon

Özkal, A., 1990. Şehirlerde Yaya Alanları ve Yayalaştırma. İ.T.Ü. Fen Bilimleri Ens., Şehir Planlama Anabilim Dalı, Yüksek Lisans Tezi, İstanbul

Pakdil, F., 2001, Yaşlı ve Özürlüler İçin Kentsel Alanların Tasarımı, I. Uluslararası Kent Mobilyaları Sempozyumu, 9-10-11 Mayıs 2001 İBB, İSTON, 353-360, İstanbul.

Renda, Y., 1996, Şehir Ve Ulaşım, Bilim Teknik Dergisi, TUBİTAK Yayını, İstanbul.
Riefstahl, R., (1941). Cenubi Garbi Anadolu'da Türk Mimarisi, Cezmi Berktin (Çev.), Maarif Vekaleti Yayınevi, İstanbul.

Untermann, R.K., 1991, Can Wepedestrianizethesuburbs, Public Streets Forpublicuse, (Ed: A.V. Moudon), Part: 2-Page: 123-132, Columbia Universitypress, New York, 0231-07599-5.

URL-1 https://tr.wikipedia.org/wiki/ Antalya erişim tarihi 2.3.2016

URL-2 https://tr.wikipedia.org/wiki/ Antalya erişim tarihi 10.6.2016

URL3. $\quad$ https://tr.wikipedia.org/wiki/ Yivli_Minare erişim tarihi 2.3.2016

URL4.http://www.antalyakulturturizm. gov.tr/TR,67641/genel-bilgi.html erişim tarihi 16.6.2016

URL5.http://www.antalya.bel.tr/calismalarimi z/ imar-ve-kentsel-iyilestirme-calismalari/ cumhuriyet-meydani-hak-ettigi-guzellige kavusacak erişim tarihi 3.5.2016

Y1lmaz, L., (2002). Antalya-Bir Ortaçağ Türk Şehrinin Mimarlık Mirası ve Şehir Dokusunun Gelişimi (16. Yüzyılın Sonuna Kadar), Türk Tarih Kurumu Basımevi, Ankara. 